\title{
THE ROLE OF ISLAMIC EDUCATION IN REALIZING SOCIAL INTERACTION BASED ON MULTICULTURALISM AMONG STUDENTS OF DIFFERENT RELIGIONS IN ELEMENTARY SCHOOLS
}

\author{
Syamsul Bahri \\ syamsulbahri167@ymail.com \\ Student of Multicultural Islamic Religious Education Doctoral Program \\ Universitas Islam Malang, East Java, Indonesia
}

\begin{abstract}
Islamic Religious Education (PAI) in realizing multiculturalism-based social interactions in elementary schools. PAI is one lesson in the national curriculum that is taught at each educational institution. Islamic Religious Education is very appropriate to be carried out to realize harmonious social interaction among students of different religions based on multiculturalism. This research was conducted at Taman Harapan Elementary School and Bina Budi Mulia Elementary School Malang City, a private school that has multi-ethnic and multi-religious students. The problems raised in this study are how is the role of PAI in realizing multiculturalism-based social interaction among students of different religions in elementary schools? The research method used is qualitative and the research approach is phenomenology. The Researcher collected data through observation, interviews and document review. Interviews were conducted with school principals, PAI teachers and students. The research results showed that Taman Harapan Elementary School and Bina Budi Mulia Elementary School strongly supported the harmonious interaction of students of different religions in the schools. The Conducive social interactions occur in two forms, namely interactions within the classroom, and social interactions outside the classroom. The social interaction in the classroom takes place by working together, learning together, discussing and helping each other. While the interactions outside the school take place in extracurricular activities such as sports, religious holidays, arts performances, outbound, and friendship interactions in the school environment.
\end{abstract}

Keywords: PAI, social interaction, Taman Harapan Elementary School, Bina Budi Mulia Elementary School 


\section{INTRODUCTION}

Islamic religious education (PAI) is a subject in the national education curriculum which is very appropriate to integrate the values of multiculturalism. But in this decade PAI has become the talk of many academics. It is said that PAI cannot be taught only in one aspect of normative theology with rigid methods, but it needs curriculum innovations; one of them is by incorporating the values of multiculturalism.

The concrete evidence that PAI has not succeeded in producing a tolerant and inclusive generation, for example, can be seen from the results of a survey conducted by the Center for Islamic and Community Studies (PPIM) UIN Syarif Hidayatullah, Jakarta at the end of 2008. It was stated that the majority of PAI teachers and Islamic students in schools in Java are intolerant and reject religious pluralism. The survey stated that $62.4 \%$ of the Islamic religion teachers surveyed, who were from Nahdlatul Ulama and Muhammadiyah, rejected non-Muslim leadership. The survey also revealed $68.6 \%$ of respondents rejected the principles of non-Muslims being a rule in their schools and $33.8 \%$ rejected the presence of non-Muslim teachers in their schools. Around $73.1 \%$ of the teachers did not want adherents of other religions to build places of worship in their neighborhoods. While $87 \%$ forbid students to study other religions. Meanwhile, as many as $21.3 \%$ of respondents want the death penalty for those who apostate or leave Islam. ${ }^{1}$

The similar findings were also reported by the Institute for Islamic Studies and Peace (LaKIP). The LaKIP survey conducted in October, 2010 - January, 2011 involved 590 respondents from a total of 2,639 PAI teachers and 993 Muslim students from a total of 611,678 junior and senior high school students, in 59 private schools and 41 public schools in Jakarta, in Jabodetabek. The results of the survey included $41.8 \%$ $63.8 \%$ supporting intolerance and violence against non-Muslim citizens. The survey results also mentioned that as many as $57.2 \%$ of teachers and $45.2 \%$ of students disagreed if non-Muslims became principals. ${ }^{2}$

${ }^{1}$ Suhadi (editor) dkk, Mengelola Keragaman Sekolah, Gagasan dan Pengalaman Guru, (Yogyakarta: CRCS, PPs UGM, 2016), p. 74

${ }^{2}$ Suhadi (editor) dkk, Mengelola Keragaman Sekolah ..., p.75, the results of this survey were also published in Media Indonesia, 27 Feb 2011. The reality of conflict in Indonesia which is closely related due to religious issues can be referred to in Alo Liliweri's book, M.S, Prasangka Konflik: Komunitas Lintas Budaya Masyarakat Multikultur, Cet. II, (Yogyakarta: LKiS Yogyakarta, 2009). Dody S.Truna, Pendidikan Agama Islam Berwawasan Multikulturalisme, Telaah Kritis atau muatan Pendidikan Multikulturalisme dalam Buku Ajar Pendidikan Agama Islam (PAI) di Perguruan Tinggi Umum Indonesia, (Seri Disetasi diterbitkan oleh Kementerian Agama RI, 2010). Imron Mashadi, Pendidikan Agama Islam Dalam Perspektif Multikulturalisme, Jakarta :Balai Litbang Agama, 2009 
The data above explains that the PAI curriculum has not accommodated the values of multiculturalism and even tends to be exclusivistic. If only the PAI subjects were packaged with exclusivity, it would create a gap between expectations for graduates, because graduates would practice the intolerance and exclusivity. Based on the data above also requires that PAI can have an adaptive role to form the multiculturalistic student personality. The different things happen in schools that have multi-religious students. The researcher's observation in Taman Harapan Elementary school, the researcher witnessed directly children playing in school complexes. These children have different beliefs (religion), because the school is a school that has multiethnic and multi-religious students. ${ }^{3}$

In the midst of multi-religious and multi-ethnic schools in Taman Harapan Elementary School, there is no class separation based on religion, except that only students are separated during their respective religious classes. The phenomenon that occurs in the reality provides information to the researcher that the Taman Harapan Elementary School environment appears to support conducive social interactions as a culture of the school. The process of social communication and social interaction that takes place at the school is social capital to carry out multicultural education. It is called social communication because the communication patterns have occurred between students of different backgrounds. And it is called as social interaction because among the interfaith and ethnic students have engaged in social relations that are marked by their association, and the cooperation that is carried out.

In another case, how the role of Islamic religious education in schools with very few Muslim students (the minority of Muslims); At Bina Budi Mulia Elementary School, Malang, the number of students is only 8 Muslims. Each Grades 1, 2 and 6 have a Muslim student. In grade 3 , there are 3 Muslim students. And grade 4 there are 2 Muslims, while in grade 5 there is none. ${ }^{4}$ There are 4 religious students in the Bina Budi Mulia Elementary School, namely Christian, Catholic, Buddha and Islam. The majority of students' religions in this school are Catholic. ${ }^{5}$

The students do not separate classes according to religions, except only during religious classes. Besides teaching Islamic lessons in schools in a private way, it turns out that this PAI teacher is also invited by students' parents to come home and teach privately. Some of the students' parents care about religious practices for their

\footnotetext{
3 Observation on the basketball court at Taman Harapan Elementary School, Thuesday 14 Feb 2017

${ }^{4}$ Interview with PAI teacher Bina Budi Mulia Elementary School (SD-BBM), 12 April 2018

${ }^{5}$ Interview with school principal SD-BBM, 10 April 2018
} 
children. So that, not only at school, for the sake of their children's religious abilities, they invite PAI teachers to teach privately at home. Almost the same as Taman Harapan Elementary School, in this school, it turns out that the parents' religion of Muslim students is indeed different. Some students have Muslim fathers while the mother is Catholic, and vice versa. Although this Muslim student comes from a multireligious family, the informant said that he continues to teach seriously in order this child understand his religion, and practice his religion correctly.

The explanation above reveals the condition of the multi-religious students at Bina Budi Mulia Elementary School and the practice of Islamic religious studies carried out by PAI teachers. The explanation above also shows that the values of multiculturalism are embedded in the environment of Bina Budi Mulia Elementary School. The values of multiculturalism in the learning of Islam are also conveyed in the school's PAI curriculum. PAI is a forum that is quite effective to include multiculturalism, because the contents contained in it aim to create people who are devout, have piety, good character, and carry out God's commands as caliphs on the earth. In other words, the values of multiculturalism such as tolerance, equality, cooperation, are in harmony with the goals of Islamic education itself. ${ }^{6}$

Thus, this research is directed to gain an understanding of how Taman Harapan Elementary School and Bina Budi Mulia Elementary Schools play a role in implementing Islamic Religious Education based on Multiculturalism. Therefore, to conduct further research, the researcher takes the title of this study with "The Role of PAI in Creating Multiculturalism-Based Social Interaction in Taman Harapan Elementary School and Bina Budi Mulia Elementary School in Malang."

\section{RESEARCH METHODS}

This study seeks to understand the role of Islamic Religious Education in realizing social interactions based-multiculturalism among students of different religions in elementary schools. For this reason, this study is categorized as a qualitative research. According to Creswell, qualitative research begins with the assumption and uses of interpretive / theoretical frameworks that make or influence the study of research problems related to the meaning imposed by individuals or

6 Lebih lanjut lihat M. Amin Abdullah, "Pengajaran Kalam dan Teologi di Era Kemajemukan; sebuah Tinjauan Materi dan Metode Pendidikan Agama.(hal.14)" Abdul Munir Mulkhan, "Humanisasi Pendidikan Islam" in Tashwirul Afkear, Jurnal Refleksi Pemikiran keagamaan dan Keindonesiaan, (hal.17-18). Edisi No.11 Tahun 2001. 
groups on a human social problem. For this reason, the data analysis in qualitative research is both inductive and deductive and forming various patterns or themes. ${ }^{7}$

The characteristics of qualitative research as terminology above according to Creswell include a) the natural environment, b) the researcher as instruments, c) the various methods, d) the complex thinking through inductive and deductive logic, e) the meaning of the participants, f) the new designs and dynamic, g) the reflexivity, and h)the holistic discussion. ${ }^{8}$ Referring to this view, the natural environment intended in this study is Taman Harapan Elementary School and Bina Budi Mulia Elementary School, and the research instrument is the researcher himself.

As for the research approach is called phenomenology. This phenomenological approach is important for researcher to reveal individual or communal experiences in multi-ethnic and multi-religious schools. Bogdan \& Biklen said:

Reseacher in the phenomenological mode attempt to understand the meaning of events and interactions to ordinary people in particular situation... what phenomenologist emphasize, then, is the subjective aspects of people's behavior. They attempt to gain entry into the conceptual world of their informant in order to understand how and what meaning they construct around events in their daily lives. ${ }^{9}$

So, the phenomenological approach that the researcher did towards the two schools attempted to reveal and describe the phenomena that occurred in the school community. After discovering this phenomenon, the researcher combines and describes in the form of words so they can explain the social and cultural conditions of the school community. ${ }^{10}$ The researcher come to the school to witness the condition of the school environment directly, and observe the learning process and the ongoing social interactions at the school. Then collect the data through participant observation, in-depth interview, and documentation studies. The Interview was conducted with school principals, PAI teachers, and students. The instrument tools used in this case are

${ }^{7}$ John W. Creswell, (terj) Ahmad Lintang Lazuardi, Penelitian Kualitatif \& Desain Riset, Memilih antara Lima Pendekatan, (Yogyakarta: Pustaka Pelajar, 2015), hal, 59. Lihat juga Norman K. Denzim dan Ivonna S. Lincoln, Qualitative Research, Ter. Dariyanto, (Yogyakarta: Pustaka Pelajar, 2011), p.3-4

${ }^{8}$ Creswell, p. 60-63

9 Robert C. Bogdan \& Sari Knopp Biklen, Qualitative Research for Education,: An Introduction to Theory and Methods, London: Allyn and Bacon, 1998), p. 25-26

10 "Phenomenologist believe that multiple ways of interpreting experiences are available to each of us through interacting with others, and that it is the meaning of our experience that constitutes reality. Reality, consequently, is "social constructed”Bogdan \& Biklen, hal. 26 
field notes, interview notes, and documents in the form of files about school profiles, lesson plans and textbooks.

\section{RESEARCH RESULT}

The role of PAI in realizing the social interaction based multiculturalism.

Based on the problems in this study, the role of Islamic Religious Education in realizing the social interactions based multiculturalism are:

\section{a) Formulating the objectives of Islamic Religious Education based on multiculturalism}

In learning religious education in Taman Harapan Elementary School, it has three similar goals, namely:

- Give the insight of the religion diversity in Indonesia.

- Increase the faith and devotion of students according to their respective religious beliefs.

- Develope an attitude of tolerance among religious communities. ${ }^{11}$

PAI teachers have their own lesson plans that still refer to the objectives set.

The PAI curriculum at Taman Harapan Elementary School follows the 2013 curriculum established by the Ministry of Education and Culture. The book used is Islamic Religious Education and Character, published by the Ministry of Education and Culture, 2016. The book was compiled by Dr. Mohd. Mansjur, S.Ag, Drs. H. Zubeir, M.Pd.I, H.M. Zaenuri, S.Ag, Nur Shodiq, S.Ag, Drs. Ftachul Munir, with the coordinator H. Chairul Arif, S.Ag. The editor of the book is KKG PAI Team Malang City. Therefore PAI teachers, as reported to the researcher, in making lesson plan still refers to the national curriculum and the goals of the school.

From the explanation above, the following diagram explains the PAI oriented multiculturalism that is taking place at Taman Harapan Elementary School:

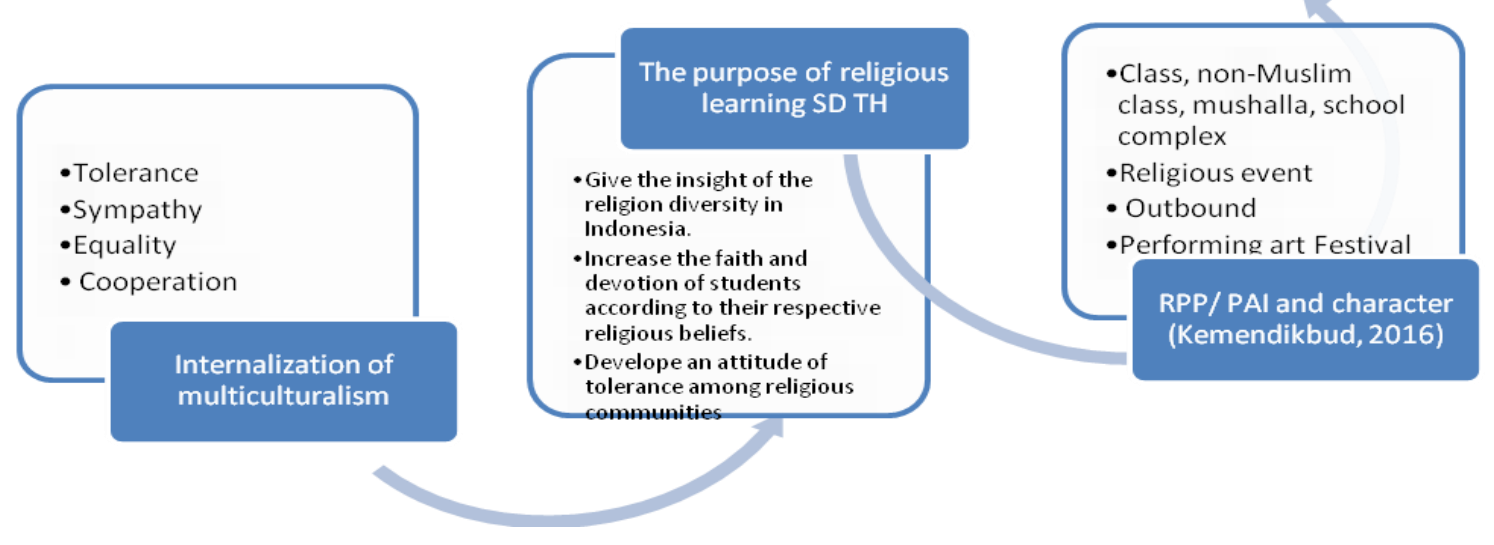

11 School Profile Documents 
At SD Bina Budi Mulia, the researcher looked at the school profile documents given by the school principal. In that profile, the school's vision and mission stated that the school's vision is; "The formed of a person who is religiously obedient, superior, innovative, global-minded, and respects others and nature, God's creation." While the missions staded are 1) instilling religious values based on the students' religion and beliefs; 2) instilling and growing children's character early on; 3) equipping the students with science and technology according to the demands of the times; 4) improving the caring attitude towards others and the environment. ${ }^{12}$ Based on these objectives it can be concluded that the multiculturalism aspect has been integrated in the objectives of Islamic religious education at the school.

The principal in the interview session told the researcher that this school has a national curriculum, so this school does not privilege one religion and ignore another religion. The principal recognizes that as the principal, he must equalize all students even though they come from different religious sectors. He conveyed to the researcher that the major religious events were not held much. The celebration of religious holidays is only carried out nationally (national calendar). He said:

"... if every religious event in every religion is made then it will proclaim a considerable amount of time and is not in accordance with the national curriculum. So in this school mission stated that one of the mission of this school is to instill religious values in accordance with the religion and beliefs of students. ${ }^{13}$

Based on the interview excerpt above it can be explained that the Bina Budi Mulia Elementary School accommodates the characteristics of all religions, and does not discriminate the minority religions in the school.

\section{b) Integration of multiculturalism content in PAI subjects}

Internalization of the multiculturalism values in PAI learning is done by including it in (Lesson Plan (RPP). For example the theme in RPP grade 6 is "Let's Learn Surah al-Kafirun," with the sub-theme "Reading Surah al-Kafirun." One competency listed is respecting and comprehending the religion he adheres to (K1), while one of the Basic Competencies is: having a tolerant attitude and sympathy to others as an implementation of understanding the contents of the surah al-Kafirun. The achievement indicators include reading and writing the surah al-Kafirun, and can

\footnotetext{
12 School Profile Document SD BBM,taken on 10 April 2018

13 Interview with school principal SD BBM, (W-2A/S-1/020-030)
} 
exemplify tolerant behavior and sympathy as an implementation of understanding the content of surah al-Kafirun. ${ }^{14}$

Internalization of the values of multiculturalism in the RPP is carried out integrally, with the insertion in Standard Competencies, Core Competencies, and Learning Achievement Indicators. In other words the integration is done additively. Besides the students are directed to be able to read and write surah al-Kafirun. They are also expected to be able to translate and understand the contents of the surah alKafirun. The most important thing is that with the existence of Surah al-Kafirun, students can know their religious identity correctly, be tolerant and sympathize with other different religions. Islam should not be mixed well with other religions, because the concept of faith is different. Therefore "we convey to the student that Surah alKafirun explains to us that the religion of Islam is different from other religions. We should not mix religions, for example today is Christian the next day is Muslim, but must be strict in our religion. And this Allah's command - meaning surah al-Kafirun - encourages us to respect and appreciate other religions. " 15

Besides teaching about theological-normative about Islam doctrine, ${ }^{16}$ this teacher slipped the values of tolerance and social equality in her lectures in class.

"We teach tolerance, lakum dinukum waliyadin, respect each other, in the same association is not different. Surah al-Kafirun, al-Maidah verse 2 about helping each other in the virtue is our reference. Students in my class are all Muslims. When (religious lessons) the children enter to their respective religious classes. They line up in front of the class according to their respective religions. " 17

Internalization of the values of multiculturalism in PAI in Taman Harapan Elementary School is derived from the Qur'an itself. Surah al-Kafirun, for example, teaches its readers to truly understand their own religion, there is no compulsion to embrace other religions. Surah al-Kafirun explained among fellow religious communities the opportunity to worship according to their respective religions. Likewise Surah Al-Maidah verse 2, (what the teacher intended is cooperation efforts to help each other, ....and help one another in goodness and piety, and do not help one another in sin and aggression; and be careful of (your duty to) Allah; surely Allah is

\footnotetext{
14 PAI lesson plan Grade 6/ Interview with PAI Teacher

15 Interview with PAI teacher. Kafirun)

16 Namely about the theological-normative consequences of Islam (the essence of surah al-

${ }^{17}$ Interview with PAI teacher.
} 
severe in requiting (evil). In this verse it is emphasized that every individual is encouraged by Allah to help in good, but it is forbidden to help in matters of evil. With this presentation, as the teacher reports, he hopes that the children can work together even if the friend is a non-Muslim. ${ }^{18}$

In learning in the classroom, PAI teachers also use learning media as an internalization of the values of multiculturalism. For example when teaching angel names, display the room about the names of angels and their assignments are available in the classroom. "Every time we are monitored by angels recording good and bad deeds, in order we get a good charity record book, we must always do good things." 19 Furthermore, the process of internalizing multiculturalism values that is conveyed in class when the learning process is explained:

"We include (multiculturalism-explanation) in learning, such as about material admirable attitude, there are admirable attitude material; help each other, sincere, tawadhu; there we enter. I enter. I do not have to learn in the class, but sometimes I take it to the field all. Sometimes they take me to the Christian room, I want to teach them; This is another religion, like this. So what do we do when they worship? Do we have to come or we have to respect it. No need. They will spontaneously answer everything. But there are children who say they want to come. Not allowed to come but we must respect them. "20

\section{c) PAI teacher as a facilitator}

As a teacher, PAI teachers do not act as learning centers. PAI learning in the class is done based on the principle of student center, where students are the subject of learning itself, and are actively involved in learning. As stated in the lesson plan of Grade 6, there are approaches, strategies and methods in learning. The approach used is scientific, the strategies used are cooperative (cooperative learning) and the methods are brainstorming, numbered head together, assignments, questions and answers, discussions and field experiences. The media used are writing posters, cards written Surah al-Kafirun, and multi media (interactive CDs and videos). ${ }^{21}$ In addition, PAI teachers also act as facilitators of Muslim students to interact with non-Muslim students. This is done by doing learning outside the classroom.

\footnotetext{
18 Interview with PAI teacher.

${ }^{19}$ Interview with PAI teacher.

${ }^{20}$ Interview with PAI teacher.

${ }^{21}$ Lesson plan document grade 6
} 
The places of learning outside the classroom, for example in Mushalla. Learning in Mushalla is usually done when there is prayer training. In addition, the internalization of multiculturalism values outside the classroom also takes place through the Performing Arts. In the Performing Arts, the students usually collaborate to display their own creations. Here between Muslims and non-Muslims directly involved to prepare themselves to present the results of their creations. In addition there is also learning outside the classroom through outbound. Here all students are mixed and even sometimes indistinguishable between Muslims and non-Muslims. Every religious event or religious ritual of Muslim students can witness non-Muslim religious worships, even if they do not participate in them. ${ }^{22}$ By witnessing nonMuslim religious worship, the students have already had the view that is called religious differences are as same as the different ways of worship. And to respect the religion of others, a Muslim also respects the practice of worship. "They play together, pay attention, ${ }^{23}$ that they are multi-religious. It's time for religion to learn, it's time to play, yes to play. There is no difference when they are playing. " 24

Asking students to visit other religious classes is part of practically introducing religious pluralism directly. This is one method of learning by utilizing the school community. In addition, in giving a task, "sometimes there are unstructured learning, like studying at home. I asked them to look for as much information as possible from the newspaper, now it is sophisticated, the task is to search in the Net (internet). Later I asked them to look for the religious tolerance, whatever needs to be done what should not be done. " 25 .

Children at the age of 5-12 years (elementary school age) are the ideal age to be taught the basics of religion, such as reading the Qur'an, introducing the pillars of faith and the pillars of Islam, prayer, and so on. Islamic Religion Studies in Bina Budi Mulia Elementary School is taught by a Muslim teacher. He teaches from grade 1 to grade 6. This means that if one class has 3 hours of Islamic study, then he teaches as much as 15 hours in a week. This PAI teacher conveyed to the researcher that in teaching he still refers to the national curriculum, both the books used, up to administration or learning tools such as syllabus and lesson plans. "Here (this school, pent) is required to use RPP. Because, this is indeed a national school. When it is

\footnotetext{
22 Interview and photo document

23 The teacher pointed to the students who were playing when the interview with the researcher was on going.

24 Interview with PAI teacher

25 Interview with PAI teacher
} 
accredited, there must be instruments, such as RPP, syllabus and others. Even though there was only one person in the class. " ${ }^{26}$

In addition, the Bina Budi Mulia Elementary School has a compulsory program which is implemented every semester, namely the Faith Building Program. In this Faith Building Program, every students will be taken to a place of worship according to their religion. At the place of worship, they will be fostered based on their respective beliefs and religions. Besides the principal's presentation, the PAI teacher also said that the Faith Building Program is very important for students. This is because they will be introduced by other people (religious leaders, for example in mosques) about their religion. Including the school canteen, because the religion adopted by students at this school is different, said an informant, this school canteen provides halal food.

\section{The Forms of Social Interaction Based on Multulturalism at Taman Harapan Elementary School and Bina Budi Mulia Elementary School}

Based on the role of PAI above, the forms of social interaction between Muslim students and non-Muslims occur in various ways and places. The forms of social interaction between Muslim students and non-Muslim students occur in the classroom and outside the classroom. The social interaction occurs in the classroom because there are no groupings of students based on their religion. They are in one class except only on religious classes are separated. The forms of interaction in the classroom are;

\section{a) Group discussion}

The interaction between Muslim students with non-Muslim students in the classroom occurs when in learning and outside learning. Before the lesson begins, the interaction that intertwines between Muslim students and nonMuslim students is exchanging greetings with one another, doing class cleanliness pickets together, as well as discussions about subjects or things outside the subject. The researcher's observation in class before learning, students open textbooks and they discuss lightly related subjects to be taught on that day. In addition, the teacher who teaches creates group discussions in the learning process.

\section{b) Making friends}

The friendship among students in the two schools is no obstacle. The social interaction becomes friendship not only occurs when they are in school, but also outside of school such as at home or in their neighborhood. This is because

\footnotetext{
${ }^{26}$ Interview with PAI teacher SD-BBM.
} 
there are students who live nearby (neighbors) even though their parents are of different religions. At a student's birthday, another friend celebrated at his home, and among the friends present were non-Muslim students. The researcher pays attention that Muslim children make good friends with nonMuslim students, they do not create their own outgroups because of this religious difference. and they do not feel superior even though the number of non-Muslim students is greater in the two schools.

\section{c) Academic competition}

Beside the social interaction occurs on learning and friendship, more intense interactions also occur in student academic competition. They are competing to get the highest rank in school or good test results. In the researcher's observation in the class, the teacher gives grades to children's exercise books differently. The students show their grades to other friends, and feel happy if their grades are better than other friends. This competition is considered by the teacher as a positive thing because through academic competition, in addition to increase student discipline, it can also foster good relations between students of different religions.

Beside the social interaction in the academic domain and in the classroom when learning, the social interactions based on multiculturalism also occur outside the classroom. The forms of interaction between Muslim Students and Non-Muslim Students Outside the Class, namely:

\section{a) Play in the school complex}

The social interactions based on Multiculturalism often occur when the students play outside the classroom. Taman Harapan elementary school complex and Bina Budi Mulia Elementary School are used by Muslim and non-Muslim students to play together. This can be seen when students of different faiths play in the school grounds. "They play together, pay attention (Mrs. Arofah points towards the children), that they are multi-religious. It's time for religion to learn, it's time to play, yes to play. There is no difference between them when playing." ${ }^{27}$ Students' play groups at two schools are not based on religious differences, they play without distinguishing religious status.

\section{b) Sharing in the School Canteen}

The social interaction among students of different religions also occurs at the school canteen. Theoretically the interaction outside the hours of learning is more effective than in the classroom, this is because the settings outside the

${ }^{27}$ Interview with PAI teacher (W-A1/S-2/057-058). 
classroom occur naturally without intervention from others. The situation in the school canteen, Muslim students practice the attitude of sharing the food and drinks they buy. Taman Harapan Elementary School and Bina Budi Mulia Elementary School have a halal canteen, means that all students even though they have different religions can have snacks at the canteen.

\section{c) Performing arts and faith-building programs}

Students at Taman Harapan Elementary School perform art performances at the end of each semester. The art performances are attended by students from across religions, they present art, such as dances, plays and songs, and these art performances are contested by schools. The students participated to make the event success, and they joined together to take part in the art performance. While at Bina Budi Mulia Elementary School there is a Faith-Building program. This Faith Building Program is a semester-long agenda that is routinely occured at this school. This program is done by each religion teacher.

\section{DISCUSSION}

To uncover the role of Islamic religious education and social interaction, there are two things that need attention. First, the role of religious education. Related to the issue of inter / interfaith interaction, religious education is carried out in schools has a quite large role. But this role actually also depends on the religion teacher itself. The students will be tolerant or intolerant depending on how the religious teacher, through a set of abilities, understands the texts of religious teachings to be communicated to the students.

In the Islamic perspective, the multicultural education that is based on democracy, equality, and justice turns out to be compatible with Islamic doctrines and the historical experience of Muslims. ${ }^{28}$ This existence is found in Surah al-Shura: 28 , 29 al-Hadid: $25,{ }^{30}$ and al-A'raf: $81 .^{31}$ The basic competence of multiculturalism

\footnotetext{
${ }^{28}$ Further, the compatibility of Islam in the study of multiculturalism can be referred to in Mochammad Tolchah Hasan's book, Pendidikan Multikultural, Sebagai Opsi Penanggulangan Radikalisme, Malang: Unisma, 2016). Mun'im Sirry (editor) Fikih Lintas Agama, (Jakarta: Paramadina, 2004). Muhammad Ibrahim Ali Muhammad Ahmad, Dustur Madinah, (Markaz al-al'alamy, 1998). Imron Mashadi, Pendidikan Agama Islam Dalam Perspektif Multikulturalisme, (Jakarta :Balai Litbang Agama, 2009). Ali Maksun, Pluralisme dan Multikulturalisme Paradigma Baru Pendidikan Agama Islam Indonesia, (Malang: Aditya Media Publising, 2011).

29 "And (for) those who accept (obey) the call of their Lord and do the prayer, while their business is (is decided) with deliberation between them; and they spend part of the fortune that We give to them."

30 "Indeed, we have sent our prophets by bringing the real evidence and we have sent down with them AlKitab and balance (justice) so that bumans can do the justice."

31 "And among the people that We created there are people who give guidance with the rights, and with those rights (also) they do justice."
} 
integration in learning activity is a command in the Qur'an. Namely creating a society that is honest, trustworthy, democratic, united, tolerant, affectionate, work ethic and so on, (QS.39: 33, 16: 4,105, 2: 256, 49: 10-13, 10:99, 4: 1,59, 3: 103,105, 28:77). Namely by accommodating all aspects of human resources from different circles. (Qur'an, 16: 93, 11: 118, 42: 8, 49:13). The multicultural education through religious education (Islam), can be done through the empowerment of curriculum slots or the addition or expansion of learning outcomes competencies in the context of fostering noble morals by emphasizing various competencies. Then, the multicultural education through Islamic religious education must also be carried out in a deductive approach started with the study of verses in relevant themes, then developed into religious norms, both legal and ethical norms. ${ }^{32}$ This is consistent with the role of PAI in two schools. PAI teachers at Taman Harapan Elementary School and Bina Budi Mulia Elementary School integrate the values of multiculturalism in the classroom learning design. And make verses of the Qur'an with the interpretation of the values of multiculturalism.

Second, The social interaction. According to Bonner, the social interaction is a relationship between two or more people, so that the behavior of one individual influences, changes, or improves the behavior of another individual, and vice versa. ${ }^{33}$ Meanwhile, according to Young, the social interaction is mutual contact between two or more people. Thus in the social interaction there is mutual stimulation and reaction between the two individual parties. ${ }^{34}$

Seen from the point of view of the subject, there are three kinds of social interactions, namely: (1) Interaction between individuals; (2) Interaction between people and their groups, and vice versa; and (3) Interaction between groups. Meanwhile, if it is seen from the terms of the way, there are two kinds of social interactions, namely: (1) Direct interaction, namely physical interaction, such as fighting, sex, and so on; and (2) Symbolic interactions, i.e. interactions using language (oral / written) and other symbols (signs), and so on. While, based on the shape, according to Selo Soemardjan there are four types of social interaction, namely: (1) Cooperation, (2) Competition, (3) Conflict, and (4) Accommodation, namely a form of settlement of the dispute. ${ }^{35}$ Based on this theory, the social interaction in the two

32 Dede Rosyada, Pendidikan Multikultural di Indonesia; Sebuah Pandangan Konsepsional, dalam Jurnal Sosio Didaktika: Vol. 1, No. 1 Mei 2014, p.10

33 Ary H. Gunawan, Sosiologi Pendidikan, Suatu Analisis Sosiologi Tentang Berbagai Problem Pendidikan, (Jakarta: Rineka Cipta, 2000) p. 31.

34 Ari...,p. 31

35 Ary..., p. 32 
schools takes place directly, namely through group discussions, friendships, game friends, cooperation, academic competition and sharing in the school canteen. This means that social interaction is in accordance with the views of experts.

PAI has a role in influencing students' social interactions based on multiculturalism, and this must lead to the curriculum. ${ }^{36}$ Because it is basically called PAI with multicultural insight should promote core values which depart from religious teachings that emphasize the principles of human dignity, justice, equality, freedom of responsibility, and democracy. The aim is to instill students' habit on how to respect and embrace religious, ethnic and cultural pluralities; dare to state the attitude that differences in religions are not the same as inferiority, and weakness; and recognizing diversity as an integral part of the reality of Indonesian life. ${ }^{37}$ Therefore, the research results on Taman Harapan Elementary School and Bina Budi Mulia Elementary School are in accordance with the opinion above.

In the National Education System Law No. 20 year 2003 explained in article 37 paragraph 1 which reads: "Religious Education is intended to form students into human beings who believe and devote to God Almighty and have good morals". Islamic Religious Education is a part of national education related to aspects of attitudes and values, namely: fostering attitudes and behaviors and fostering personality. Therefore Islamic religious education has a very important role in supporting national development. The Government Regulation No. 552007 related to Educational Institutions, in Chapter II article 2 paragraph (1) it is mentioned: The religious education functions to form Indonesian people who believe in and fear God Almighty and have noble character and are able to maintain peace and harmony in inter and interreligious relations. Seen from the function of religious education above, after obtaining religious education students are expected to become individuals who have spirituality that is believed and devoted to Allah Almighty. In Islamic education, the religious education is known as Islamic Religious Education, which covers a variety of disciplines such as aqeedah morals, Islamic history, Islamic Jurisprudence (Fikih), al-Qur'an and Hadith. Whereas, in the schools such as elementary schools, religious education is referred to as Islamic Religious Studies. But these two educational institutions have similarities in the conception of functions, namely forming the personality of students who have noble character.

\footnotetext{
${ }^{36}$ Suhadi (editor) dkk, Mengelola Keragaman Sekolah, Gagasan dan Pengalaman Guru, Yogyakarta: CRCS, PPs UGM, 2016

${ }^{37}$ Zakiyuddin Baidhawy, Pendidikan agama berwawasan Multikultural, (Jakarta: Erlangga, 2005), p.121
} 
In the function of religious education it is also emphasized that noble morals are manifested in the association between religious communities, students are expected to be able to maintain peace and harmony between religious communities. Therefore the role of PAI in Taman Harapan Elementary School and Bina Budi Mulia Elementary School is in line with the function of religious education in PP No.55 2007.

\section{CONCLUSION}

Based on the research findings and discussion above, the research question "how is the role of PAI in realizing social interaction based on multiculturalism between students of different religions in elementary schools" can be concluded as follows:

1) The role of PAI in realizing social interaction based on multiculturalism that is done in 3 ways, namely 1) the objectives of PAI are synergistically with the values of multiculturalism; 2) integrating the values of multiculturalism in PAI subjects; and 3) PAI teachers as facilitators.

2) The form of social interaction based on multiculturalism between Muslim students and non-mulsim occurs in the classroom and outside the classroom. The forms of social interaction in the classroom are group discussions, making friends, and academic competition. While the social interaction of students of different religions outside the classroom that occurs when playing in the school complex, sharing in the canteen, arts programs, and faith building programs.

In making the PAI lesson plan (RPP), PAI teacher at Taman Harapan Elementary School and Bina Budi Mulia Elementary School have included the values of multiculturalism. In incorporating the values of multiculturalism in the learning curriculum, it is done by integrating multiculturalism values such as tolerance, empathy, mutual respect, cooperation and help. This means that the values of multiculturalism are carried out in an integrative manner, with insertion in standard competencies, core competencies, and indicators of learning objectives. Thus PAI in the two schools has a role in developing a curriculum based on multiculturalism so that it can be embedded in the social interactions of students at the school.

The environment of these two schools is a locus of inculcating multiculturalism values to the students from all religions and is also carried out in social interactions between students of different religions. In other words, the school environment is a place for the application of multiculturalism values taught in the classroom through nationally published textbooks and social interaction within the school environment. Therefore, in order for students to be tolerant and inclusive, PAI based on multiculturalism needs to be implemented in the curriculum in the primary schools. 


\section{REFERENCES}

Ary H. Gunawan, Sosiologi Pendidikan, Suatu Analisis Sosiologi Tentang Berbagai Problem Pendidikan, Jakarta: Rineka Cipta, 2000

Abdul Munir Mulkhan, "Humanisasi Pendidikan Islam" dalam Tashwirul Afkar, Jurnal Refleksi Pemikiran keagamaan dan Keindonesiaan, Edisi No.11 Tahun 2001

Imron Mashadi, Pendidikan Agama Islam Dalam Perspektif Multikulturalisme, Jakarta :Balai Litbang Agama, 2009

Dede Rosyada, Pendidikan Multikultural di Indonesia; Sebuah Pandangan Konsepsional, dalam Jurnal Sosio Didaktika: Vol. 1, No. 1 Mei 2014

James A. Banks \& Cherry A. McGee Banks (editors), Multicultural Education; Issue and Perspectives, Ed.7, University of Washington, Wiley, 2010

John W. Creswell, (terj) Ahmad Lintang Lazuardi, Penelitian Kualitatif \& Desain Riset, Memilih antara Lima Pendekatan, Yogyakarta: Pustaka Pelajar, 2015

M. Amin Abdullah, "Pengajaran Kalam dan Teologi di Era Kemajemukan; sebuah Tinjauan Materi dan Metode Pendidikan Agama, dalam Tashwirul Afkar, Jurnal Refleksi Pemikiran keagamaan dan Keindonesiaan, Edisi No.11 Tahun 2001.

Mochammad Tolchah Hasan, Pendidikan Multikultural, Sebagai Opsi Penanggulangan Radikalisme, Malang: Unisma, 2016

Norman K. Denzim dan Ivonna S. Lincoln, Qualitative Research, Ter. Dariyanto, Yogyakarta: Pustaka Pelajar, 2011

Robert C. Bogdan \& Sari Knopp Biklen, Qualitative Research for Education,: An Introduction to Theory and Methods, London: Allyn and Bacon, 1998

Suhadi (editor) dkk, Mengelola Keragaman Sekolah, Gagasan dan Pengalaman Guru, Yogyakarta: CRCS, PPs UGM, 2016

Zakiyuddin Baidhawy, Pendidikan agama berwawasan Multikultural Jakarta: Erlangga, 2005 